\title{
THE REACTION OF PRIVATE SPENDING AND MARKET INTEREST RATES TO THE CHANGES IN PUBLIC SPENDING
}

\author{
Grzegorz PRZEKOTA*, Agnieszka LISOWSKA** \\ Koszalin University of Technology, Koszalin, Poland \\ *e-mail: grzegorzprzekota@wp.pl \\ **e-mail: agnieszka.lisowska@gpt.home.pl
}

\begin{abstract}
Expansionary fiscal policy is mired in controversy. Its proponents suggest that during recession, it stimulates investors' activity and has a stabilizing effect on economic growth. However, its opponents point to the costs associated with the budget deficit and public debt handling. Increased public spending may result in an increase in the interest rates, which may, in turn, hinder private investment and weaken the multiplier effect of public spending. The following study examines how private spending and market interest rates reacted to changes in public spending in Poland. The study has shown that public spending stimulates private spending, which is consistent with the Keynesian model, but it also leads to an increase in market interest rates, which is consistent with the neoclassical model.
\end{abstract}

Keywords: crowding out, public spending, private spending, interest rates, cointegration.

JEL classification: H680, E440

\section{$1 \quad$ Introduction}

One of the key aims of the state policy is to ensure a stable, long-lasting economic growth. Due to various tools of fiscal and monetary policy, fluctuations in business cycles are stabilized and proper conditions for continuous economic growth are ensured. Since private investments and private spending constitute the basis of economic growth (Zou, 2006), when the economic situation is unfavorable and private spending decreases, the state stabilizes economic growth by increasing public spending. However, this policy results in a constantly increasing budget deficit, which forces the country to contract loans. Owing to an increase in GDP, expansionary fiscal policy may have a positive impact on private spending (crowding in); however, the pressure to increase interest rates may lead to a decrease in private investment (crowding out) (Afonso, Aubyn, 2008).

In accordance with the neoclassical model, private and public sectors compete with one another for loaned funds available in the credit market (Gawel, 2004). The interest rate mechanism balances the savings and investment. Improper functioning of this mechanism results in short-term fluctuations in both employment and production (Grieve, 2004). When the government spending rises, in order to maintain balance on the capital market, interest rates need to be increased as well, which hinders private investment (Voss, 2002; Ganelli, 2003). Long-term interest rates are particularly susceptible (Kiani, 2009); still, short-term interest rates may also be affected (Uwilingiye, Gupta, 2009). It needs to be borne in mind, however, that due to a large number of factors influencing the interest rates, it is nearly impossible to establish the level of the interest rates merely on the basis of the public spending dynamics. Therefore, public spending constitutes one of many factors contributing to an increase or decrease in the interest rate (Tswamuno, et al., 2007).

However, the study of simplified economy models indicate crowding out. Aiyagari as well as Baxter and King have studied the impact of government spending on the changes of selected economic aggregates in a one-sector economy, testing the neoclassical growth model where the economy of scale income is constant and labor supply varies. These authors proved that the increase in government spending impacts private consumption significantly, as it decreases (Aiyagari, et al., 1992; Baxter, King, 1993). Alesina and others have studied the influence of remuneration level in the public sphere on the level of private investment. The study revealed that an increase in the remunerations contributes to a decline in private investment (Alesina, et al., 2002). 
In the Keynesian model, the multiplier results in a larger production increase than the initial stimulus. Therefore, it is justified to stabilize the economy during the recession by increasing public spending, which influences the amount of the disposable income. During prosperity, however, it is justified to increase taxes and, by doing so, insulate the economy from overheating (Ljungqvist, Uhlig, 2000).

The Keynesian model assumes that the interest rate sensitivity to changes in demand is low. As a consequence, expansionary fiscal policy may only lead to insignificant increases of interest rates; however, both production and income grow significantly. Moreover, due to a positive impact of government spending on investors' expectations, public spending results in an increased number of private investments. Therefore, crowding-out does not take place (Baldacci, et al., 2004). Karras has studied changes in private consumption in relation to increased government spending in a few countries. The study indicates that public and private consumptions complement each other rather than substitute one another (Karras, 1994). Chakraborty came to a similar conclusion after examining both public and private investments in India. He found no evidence to support crowding out of private investments by the public ones (Chakraborty, 2007).

A different perspective on how government spending affects private investment is represented by the $\mathrm{Ri}$ cardian equivalence. According to this theorem, the budget deficit is irrelevant to financial decisions, because when asset holders make financial decisions, they discount the expected future tax rise, which results from the increase in current budget deficit. Therefore, the increase of disposable income is regarded as nominal rather than real (Barro, 1974). In accordance with this approach, the increase in budget deficit is accompanied by present or future tax increases. Hence, while thinking about future income, decision makers (both entrepreneurs and households) will not change the previous level of expenditure and savings. As a result, interest rates will maintain at the same level (Barro, 1989; Ghatak, 1996).

\section{Aim of the study: Analysis method}

The following study aims to determine how private spending as well as market interest rates reacted to changes in public spending in Poland in the period from 2004 to 2014. Taking into account the abovementioned, the crowding-out hypothesis shall be verified. The study enabled the authors not only to verify the theoretical models, but also to gather vital information on how the economy functions.

The time-series of both public and private spending have been analyzed; the level of changeability as well as its dynamics has been determined. A simple study designed to verify the crowding-out hypothesis may also relate to how public spending dynamics affects the private spending dynamics. The study is based on the correlation analysis. However, as it was indicted in the introduction, one of the most significant consequences of public spending is its impact on the level of the market interest rates. A further study examines how WIBOR market interest rate as well as the reference rate of the Narodowy Bank Polski is shaped. It needs to be borne in mind, however, that a few scenarios are plausible, depending on how the central bank's interest rates change. Still, in accordance with the neoclassical model, crowding-out should be observed as a growing difference between the market interest rate and the central bank's interest rate as a reaction to increased public spending. This study is based on cointegration.

The concept of cointegration was introduced to economics by Engle and Granger (1987). It assumes that it is possible to determine a long-term, timeindependent balance path between given economic processes. The values beyond this path constitute short-term, time-dependent deviations from balance.

\section{Evaluation of the public and private spending dynamics}

The study focused on public and private spending in Poland within the time period from 2004 to 2014. Fig. 1 illustrates the spending of the public finance sector as well as budgetary expenditure. 

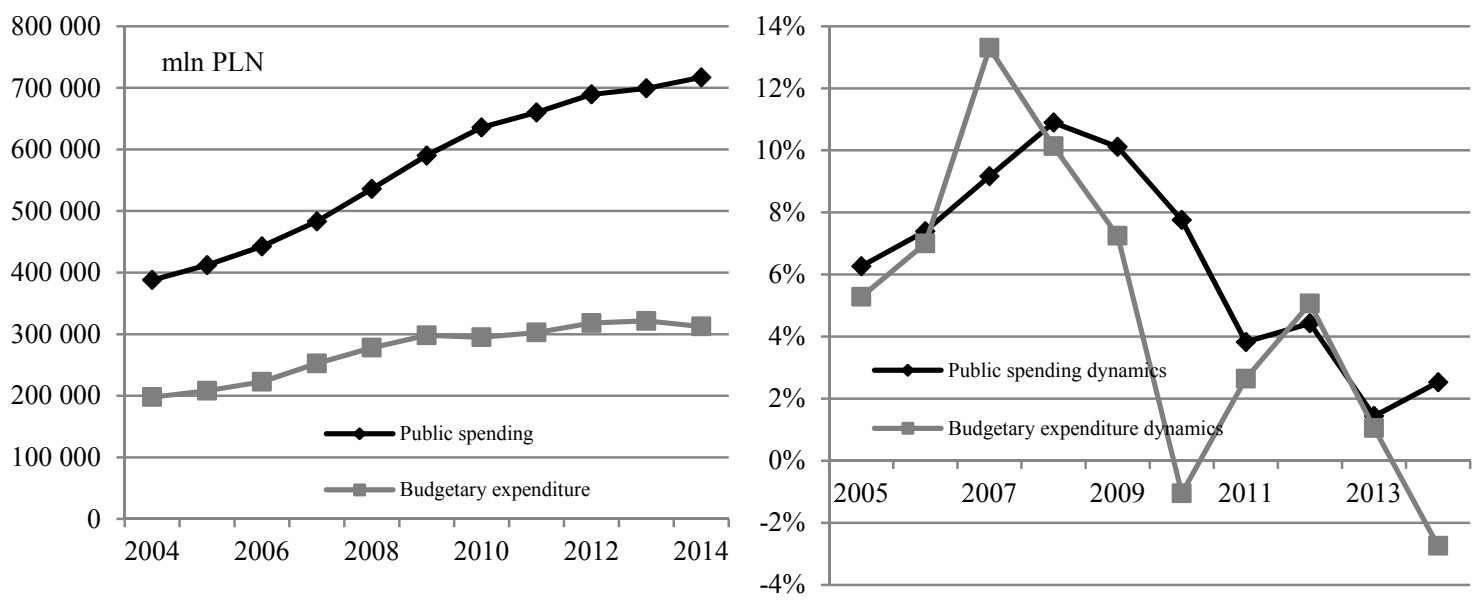

Figure 1. Public spending in the years 2004-2014

(source: the graph prepared by the authors based on data from the Central Statistical Office of Poland, Polish: GUS)

During the time period in question, all the analyzed values showed an upward trend. The years 2008 and 2009 show a clear intensification of spending.

The dynamics line graph better illustrates the changes in public spending that took place in the analyzed time period. In the years 2005-2009, public spending as well as budgetary expenditure was climbing up year by year. In 2007, the increase in the budgetary expenditure exceeded 13\% annually; in 2008, the increase of the public spending exceeded $10 \%$ annually. Since 2010, the "increase dynamics" started to slow down considerably, and in the years be- tween 2012 and 2014, it reached a level of less than $5 \%$ annually.

During the time period in question, public spending increased on average by 36,246 million PLN (6.3\%) per year, whereas budgetary expenditure on average by 13,005 million PLN (4.7\%) per year.

Fig. 2 illustrates private spending focusing on individual consumption and capital accumulation. Individual consumption grew steadily. Accumulation also experienced a gradual increase; however, in 2007, it intensified visibly and dwindled significantly in the years 2009 and 2012-2013.
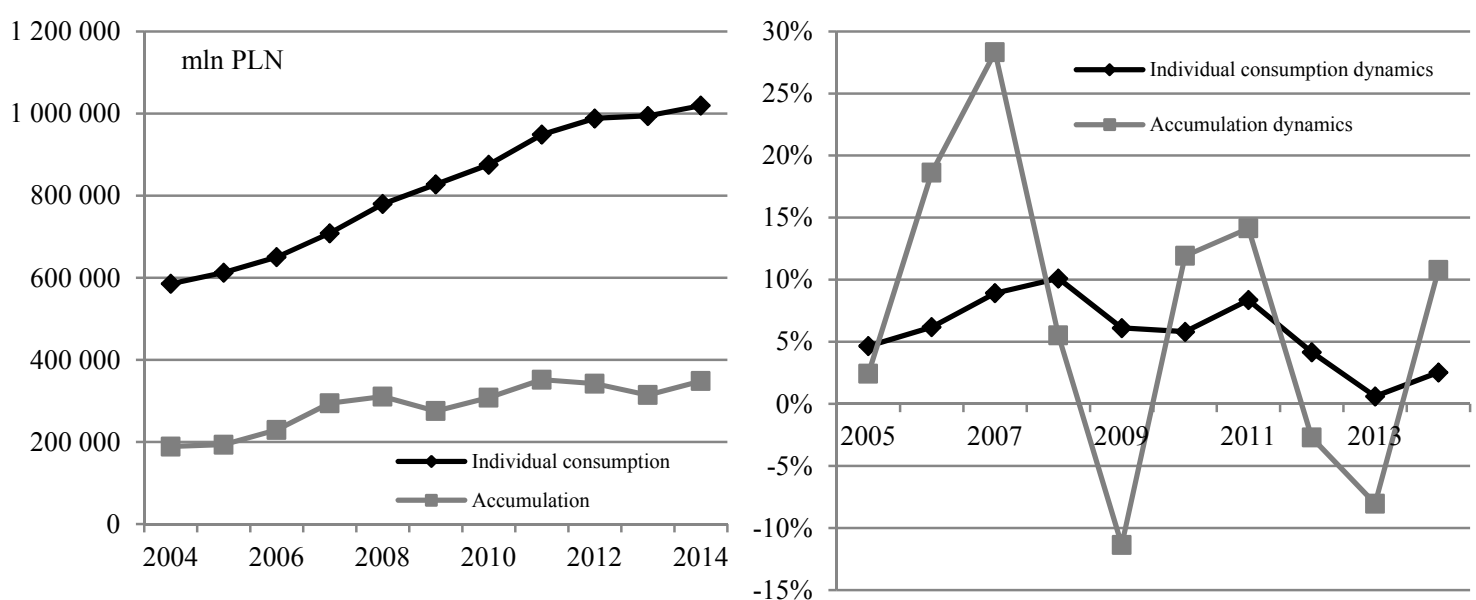

Figure 2. Private spending in the years 2004-2014

(source: the graph prepared by the authors based on data from the Central Statistical Office of Poland) 
Table 1. Evaluation of the correlation between public and private spending dynamics (source: own study)

\begin{tabular}{|c|c|c|}
\hline Correlation & Accumulation dynamics & $\begin{array}{c}\text { Individual consumption } \\
\text { dynamics }\end{array}$ \\
\hline Public spending dynamics & 0.1780 & 0.7596 \\
\hline Budgetary expenditure dynamics & 0.2421 & 0.6795 \\
\hline
\end{tabular}

In the years 2005-2007, private investment increased substantially; in 2007, the accumulation increase reached nearly $30 \%$. Two years later, accumulation decreased by $10 \%$. The following years were characterized by quite a significant rise; however, the years 2012 and 2013 were marked by another decline. Individual consumption grew steadily. During the time period in question, individual consumption climbed from around $0 \%$ to $10 \%$ per year. The most substantial increase of $10.3 \%$ happened in $2008-$ the least one, i.e., $0.6 \%$, in 2013 . The individual consumption dynamics slowed down considerably.

The value of individual spending grew on average by 48,056 million PLN (5.7\%) per year, while accumulation grew on average by 15,754 million PLN $(6.3 \%)$ per year.

Collating the results of public and private spending, it can be observed that the average growth rate of all the analyzed values is similar - varying from $4.7 \%$ to $6.3 \%$ per year. However, the fact that the average increase of individual consumption is rather slow is a point of concern. On the other hand, in the last few years, there have been attempts to limit the growth of public debt by restricting public spending and budgetary expenditure.

The examination of the relation between public and private spending dynamics and the individual consumption dynamics indicates that there exists a positive correlation between them (Table 1). Depending on the public spending category, it is a correlation of the value around $0.68-0.76$. Although the correlation between public spending dynamics and accumulation dynamics is also positive, it is considerably smaller.
Such results, consistent with the Keynesian model, indicate that growth in budgetary expenditure influences national income, stimulating private spending at the same time.

\section{Evaluation of the interest rates reaction}

A positive correlation between public spending and private spending does not prove there is no crowding-out. In accordance with the facts presented in the introduction, evaluation of how market interest rates reacted to changes in public spending is of great importance.

Fig. 3 illustrates the levels of WIBOR interest rate as well as the rediscount rate of the Narodowy Bank Polski.

These interest rates are closely related to one another; periods of their growth and decline overlap. However, what differs is the intensity of the change. Temporarily the said interest rates were at similar levels: in 2005, at the turn of 2008 and 2009, in the second half of 2012, and at the end of 2014. Still, in the second half of 2009 as well as in 2010, the interest rates levels diverge.

Fig. 4 illustrates the differences between the examined interest rates, i.e., WIBOR, the reference rate. Collating these differences with the public spending dynamics (line graph 1), it can be observed that where the public spending dynamics increases (within the time period 2005-2009), the difference between WIBOR and the reference rate becomes greater. During the period of a clear decrease in the public spending dynamics (from 2010 to 2013), the difference between the abovementioned interest rates becomes considerably smaller. 


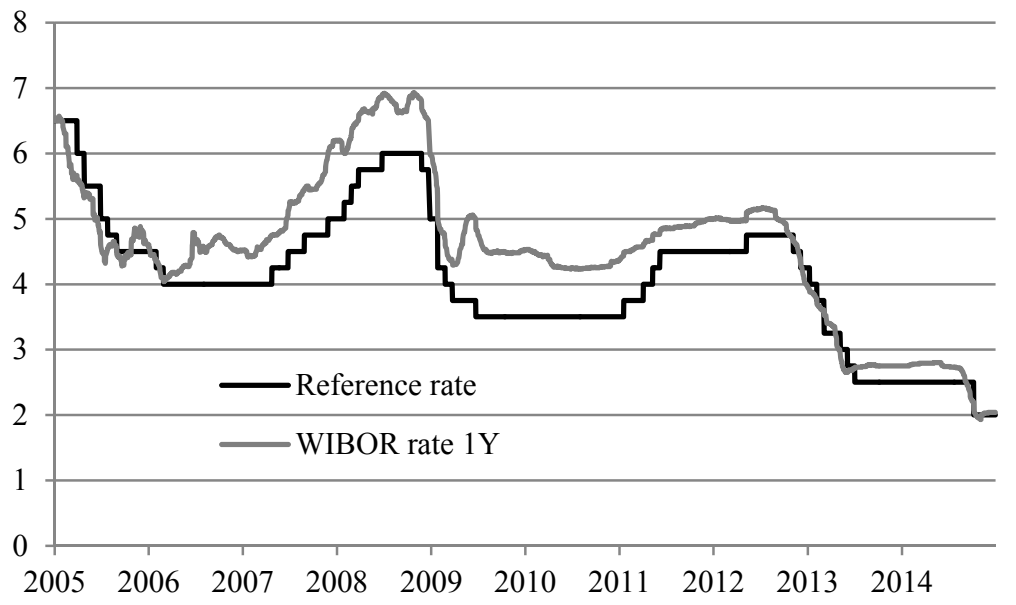

Figure 3. Interest rates levels in 2005-2014

(source: the graph prepared by the authors based on the data from the Narodowy Bank Polski)

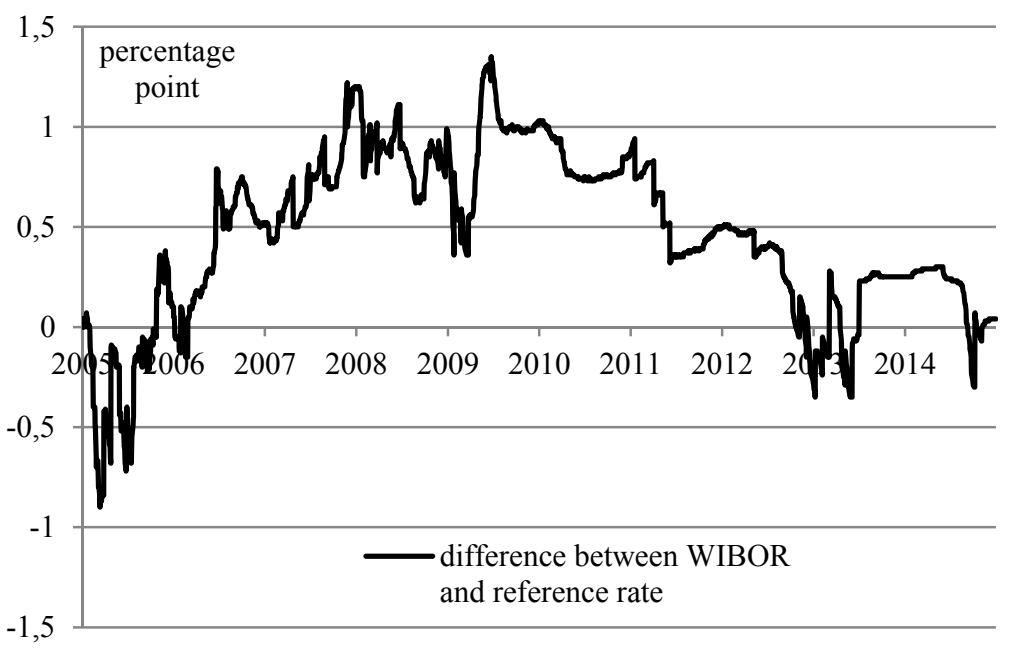

Figure 4. The difference between interest rates in 2005-2014

(source: the graph prepared by the authors based on the data from the Narodowy Bank Polski)

The year 2014 was characterized by a larger increase of public spending than the one in 2013; the difference between the interest rates rose automatically. Taking into account the fact that the difference between WIBOR and the reference rate may be considered as marginal, such results confirm the impact that public spending has on the interest rate for balancing the capital market.

In order to fully examine the correlation between the analyzed interest rates, it is crucial to determine their cointegration, which is particularly important in the context of crowding-out hypothesis. Cointegration of the time-series of the interest rates in ques- tion will prove that there is no crowding-out, since cointegration will indicate that there is a correlation between the market interest rate and the reference rate. On the other hand, the lack of cointegration might indicate crowding-out, since the lack of cointegration will indicate that there are other factors influencing the mutual balance between the market interest rate and the reference rate.

The first stage relates to examination of stationarity (Table 2). The result is a classic example where the interest rates time-series are nonstationary, but their first differences are stationary. 
Table 2. Examination of the interest rates time-series stationarity (source: authors' own calculations)

\begin{tabular}{|c|c|c|c|c|}
\hline \multirow{2}{*}{ Interest rate } & \multicolumn{2}{|c|}{ I(0) } & \multicolumn{2}{|c|}{ I(1) } \\
\cline { 2 - 5 } & t-stat & $p$ value & $t$-stat & $p$ value \\
\hline Reference rate & -1.8808 & 0.3417 & -6.7145 & 0.0000 \\
\hline WIBOR 1Y & -0.9220 & 0.7824 & -10.8770 & 0.0000 \\
\hline
\end{tabular}

Two cointegrating equations have been prepared for the interest rates in question. Fig. 5 illustrates their residual components, and Table 3 presents the parameters. The factors in both equations are statistically significant; however, their residual components are nonstationary, so these processes are not cointegrated. This, in turn, proves the abovementioned statement that the difference in the level of the interest rates in question depends on other factors.

Table 3. Evaluation of the interest rates cointegration (source: authors' own calculations)

\begin{tabular}{|c|c|c|c|c|c|}
\hline \multirow{2}{*}{ Independent variables } & \multicolumn{3}{|c|}{ WIBOR- dependent variable } & \multicolumn{2}{c|}{ Difference stationarity } \\
\cline { 2 - 6 } & Factor & $\boldsymbol{t}$-stat & $\boldsymbol{p}$ value & $\boldsymbol{t}$-stat & $\boldsymbol{p}$ value \\
\hline Reference rate & 1.1058 & 547.2399 & 0.0000 & -2.5468 & 0.1046 \\
\hline Reference rate & 1.0128 & 126.94 & 0.0000 & \multirow{2}{*}{-2.2027} & $0-2055$ \\
\hline Constant & 0.4057 & 12.04 & 0.0000 & & \\
\hline
\end{tabular}

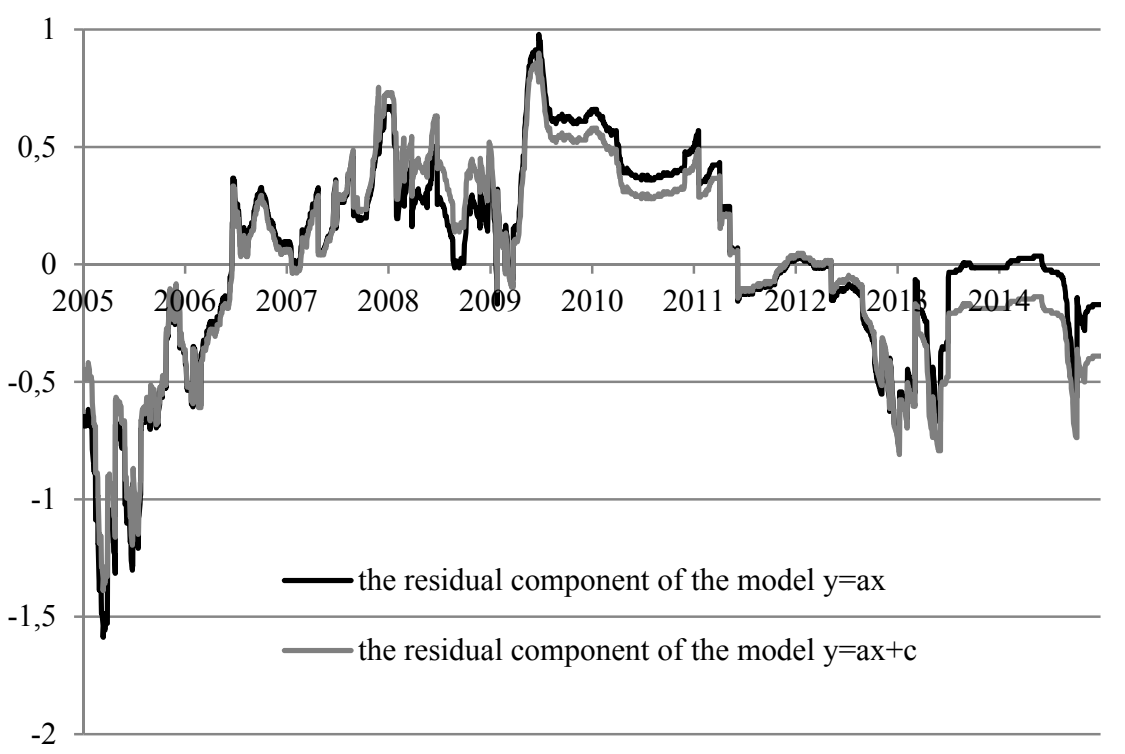

Figure 5.The residual components from the cointegrating equations of the interest rates (source: the graph prepared by the authors) 
The results from the cointegration of WIBOR interest rate and the reference rate prove that public spending has an impact on the market interest rates. Therefore, they can be considered a proof confirming crowding-out. However, it needs to be borne in mind that the time period in question was relatively short and that other factors may have contributed to the correlation between the analyzed interest rates.

\section{Conclusion}

Expansionary fiscal policy manifesting itself in increasing public spending has been mired in of controversy. Various economic schools point to potential consequences for the economy, which vary from the positive ones (stimulating national income) to the negative ones (crowding-out of private spending). The conducted study enabled the authors to confront its results with the given theoretical models.

It needs to be borne in mind that the time period in question, in the years from 2004 to 2014, might be too short to draw definitive conclusions; however, certain regularities are consistent with the proposed theories.

The first significant observation relates to the correlation between public spending and private spending. During the analyzed time period, a moderate, steady increase was observed, which is a natural phenomenon. Therefore, these were increases rather than values that were examined. The study showed a positive but not very strong correlation between budgetary expenditure dynamics and private investment dynamics. Moreover, the study revealed a positive, moderately strong correlation between budgetary expenditure dynamics and private consumption dynamics. Such results may indicate that a growth in public spending stimulates both national income and private spending, which is consistent with the Keynesian model.

Taking into account capital market perspective, the impact of public spending on the level of market interest rates is really significant. The conducted study revealed that such impact is feasible, and that it is consistent with the neoclassical model, i.e., increased public spending results in a growth in market interest rates. When budgetary expenditure in- creased, the difference between WIBOR interest rate and the reference rate increased as well.

The results of the study do not disprove any of the theoretical models discussed. It has been proven, however, that public spending not only stimulates private spending, but also causes increases in the market interest rates. Similar conclusions have been drawn from other studies (Tsung-wu, 2001).

\section{$6 \quad$ References}

[1] Afonso, A., Aubyn, M.S., 2008. Macroeconomic rates of return of public and private investment. Crowding-in and crowding-out effects. European Central Bank, Working Paper Series, No 864.

[2] Aiyagari, S., Lawrence, R., Christiano, J., Eichenbaum, M., 1992. The Output, Employment, and Interest Rates Effects of Government Consumption. Journal of Monetary Economics, 30, pp.73-86.

[3] Alesina, A., Ardagna, S., Perotti, R., Schiantarelli, F., 2002. Fiscal Policy, Profits, and Investment. The American Economic Review, 92, 3, pp.571-589.

[4] Baldacci, E., Hillman, A.L., Kojo, N.C., 2004. Growth, governance, and fiscal policy transmission channels in low-income countries. European Journal of Political Economy, 20, 3, pp.517549.

[5] Barro, R.J., 1974. Are Government Bonds Net Wealth? Journal of Political Economy, 82, pp.1095-1117.

[6] Barro, R.J., 1989. The Ricardian Approach to Budget Deficit. Journal of Economic Perspectives, 3, pp.37-54.

[7] Baxter, M., King, R.G., 1993. Fiscal Policy in General Equilibrium. American Economic Review, 83, pp.315-334.

[8] Chakraborty, L.S., 2007. Fiscal Deficit, Capital Formation, and Crowding Out in India: Evidence from an Asymmetric VAR Model. The Levy Economics Institute and the National Institute of Public Finance and Policy, India, Working Paper No. 518.

[9] Charemza, W., Deadman, D., 1997. Nowa Ekonometria. Warszawa: Polskie Wydawnictwo Ekonomiczne. 
[10] Engle, R.F., Granger, C.W., 1987. Cointegration and error correction: representation, estimation, testing. Econometrica, 55, pp.1057-1072.

[11] Ganelli, G., 2003. Useful Government Spending, Direct Crowding-Out and Fiscal Policy Interdependence. Journal of International Money and Finance, 22, pp.87-103.

[12] Gaweł, A., 2004. Efekt wypierania wydatków prywatnych przez wydatki publiczne poprzez rynek kredytowy jako zaburzenie skuteczności polityki fiskalnej w stabilizacji cyklu koniunkturalnego na przyktadzie Polski, Bank i Kredyt, VII, pp.15-24.

[13] Ghatak, A., Ghatak, S., 1996. Budgetary Deficits and Ricardian Equivalence: The Case of India, 1950-1986. Journal of Public Economics, 60, pp.267-282.

[14] Grieve, R., 2004. Macro Matters: Classical, Neoclassical and Keynesian Perspectives. University of Strathclyde, Department of Economics, 31463 Economic Thought And Method Class Notes, pp.1-17.

[15] Karras, G., 1994. Government Spending and Private Consumption: Some International Evidence. Journal of Money, Credit, and Banking, 26, pp.9-22.
[16] Kiani, K.M., 2009. Federal Budget Deficits and Long-Term Interest Rates in the USA, The Quarterly Review of Economics and Finance, 49, 1, pp.74-84.

[17] Ljungqvist, L., Uhlig, H., 2000. Tax Policy and Aggregate Demand Management Under Catching Up with the Joneses. The American Economic Review, 90, 3, pp.356-366.

[18] Tsung-wu, H., 2001. Analyzing the Crowdingout Problems of Taiwan. Journal of Economic Development, 26, 1, pp.115-131.

[19] Tswamuno, D.T., Pardee, S., Wunnava, P.V., 2007. Financial Liberalisation and Economic Growth: Lessons from the South African Experience. The Journal of Applied Economics, 4, 2, pp.75-89.

[20] Uwilingiye, J., Gupta, R., 2009. Temporal Causality between Budget Deficit and Interest Rates: The Case of South Africa. The Indian Economic Journal, 57, 2, pp.79-96.

[21] Voss, G.M., 2002. Public and Private Investment In The United States and Canada. Economic Modelling, 19, pp.641-664.

[22] Zou, Y., 2006. Empirical studies on the relationship between public and private investment and GDP growth. Applied Economics, 38, pp.12591270. 